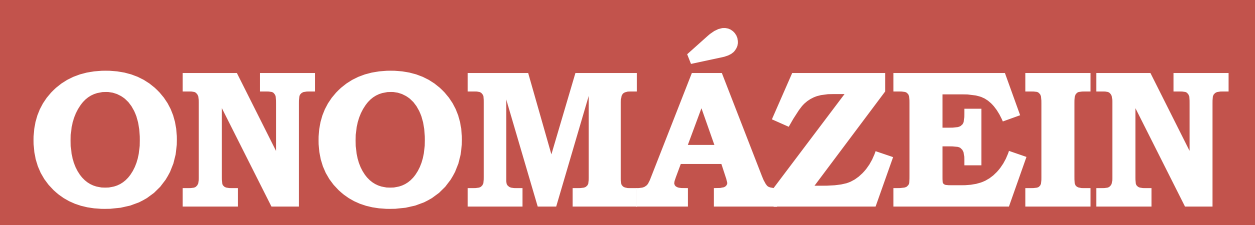

Journal of linguistics, philology and translation
PONTIFICIA UNIVERSIDAD

CATÓLICA DE CHILE

FACULTAD DE LETRAS

\title{
Stepping into the translator trainees' shoes: a descriptive study
}

\section{Ana Gregorio-Cano \\ Universidad de Granada \\ España}

\section{(C) $(i)$}

Ana Gregorio-Cano: Departamento de Traducción e Interpretación, Universidad de Granada, España. | E-mail: anagregca@ugr.es 


\section{Abstract}

In the growing field of translation pedagogy little has been discussed about the importance of key central concepts such as translation problems, translation strategies or translator competence through empirical studies. This article examines the theoretical background as the starting point of the empirical study performed at five different universities in Spain: Universitat Jaume I (UII), Universidad de Salamanca (USAL), Universidad Pablo de Olavide (UPO), Universidad Pontificia de Comillas (UPCO) and University of Granada (UGR). The research presented here focuses specifically on the development of translator competence and, particularly, the students' capacity to identify translation problems. The study results demonstrate no regular patterns for the development of translator competence within the undergraduate translators and interpreters training programs in Spain.

Keywords: translation problems; empirical study; translator competence; training programs. 


\section{Introduction}

Over recent years, research in translation pedagogy has been strengthened, especially in the context of Spain, but it is still essential to stress the need for empirical studies to shed some light on key issues for the development of the theory and practice that enable advances in the training of future translators, and the recognition of the discipline at a scientific and social level (Marco in Gambier \& Van Doorslaer, 2009: 77).

We believe that if one of the objectives of the Translation and Interpreting (TI) curricula and of translation didactics is to train future translators, it is logical to think, as pointed out by Mayoral (2001: 118), that, if the translation trainee needs work and decision making routines and different types of knowledge about the parameters that affect decision making or about different translation procedures or strategies, all of these should be addressed in a more systematic way, so that all these processes are internalized in order to prepare future translators for the work they will perform once they finish their professional training period. In this sense, we agree with Hurtado (2011) on the need to develop empirical research oriented towards understanding translator competence (TC) acquisition and not limited to purely theoretical speculations. Hurtado considers this existing deficit in empirical research as one of the challenges for Translation Studies, and, in Hurtado's own words, "[it is] crucial for translation didactics [...] to do research on the translator competence and its acquisition process" (Hurtado, 2011: 169).

In the course of our research, we consider TC as "the set of capacities, skills, knowledge and attitudes needed to translate, being fundamental the development of the capacity to recognize translation problems and the strategies to solve such problems" (Gregorio, 2014: 43) and we consider equally necessary that the development of such a capacity must be a fundamental part of translator training programs. In this vein, we share Hurtado's and Kelly's proposals (Hurtado, 2017; Kelly, 2002, 2005; PACTE, 2011a, 2011b) that suggest that TC is broken down into a series of components that are interrelated, where strategic competence (SC) is the backbone of TC.

One of the main difficulties in this research is the lack of homogeneity to refer to the different concepts used in our discipline, for example, when talking about translator competence. For this concept, in English, there are seven different denominations (Gregorio, 2014). This lack of unanimity in the conceptualization, not only in denominations, exists around basic aspects of the discipline and, especially, within the context of translator training, and when we pose the questions "What is a translation problem?," "What do we mean by ‘translation strategy"?," "How do students describe the translation problems they face when it is time to work on a translation brief?"

\section{Translator training and competence}

When translating, the expert or trainee translator faces problems that are approached in different ways whilst working on a translation brief (Gile, 2009; Shreve, 1997). There is no doubt 
that within the translation process structure, translation problems are one of the elements that are almost always present. However, despite the importance of the notion of problem in Translation and, by extension, in translator training, there is no exhaustive trajectory of analysis in Translation Studies, nor a definition of translation problems that has been accepted generally, and we do not have a framework classification for the different types of translation problems that exist (Mayoral, 2001).

While in Translation Studies we do not have a lengthy trajectory of research on the notion of translation problems as a central axis, even though some authors, such as Nord (1988, 1991, 1997), Presas (1996), Orozco (2000) or Hurtado (2011), have devoted part of their research to defining these concepts, the truth is that all this research has been practically anecdotal and has not had real repercussions in our field. This absence of agreement may be due, in part, to the high degree of complexity of the notion of translation problem and that it needs to be studied from an empirical stance, to obtain greater knowledge of the concept and, therefore, of translator competence, which would have a direct effect on the improvement of translator training.

We used the definition of translation problem proposed by Hurtado (2011: 286) for our research based on the initial definition by Nord (1988, 1991); thus, we understand translation problems as being "(linguistic, extralinguistic, etc.) difficulties of an objective nature, with which a translator can encounter when carrying out a translation assignment." Hurtado also explains that, when defining translation problems and difficulties, we should consider at all times whether the translator is an expert or a trainee (and at which level), since this will inevitably affect the process of systematization of translation problems and the problem solving criteria (Hurtado, 2011: 287).

We agree with Hurtado (2011) that the interest in knowing more about translation problems has great importance from the perspective of translator training and translation assessment, since, according to Hurtado (2011: 279), "[the translation problem] directs the development of learning objectives and the comparison of the translation to the original text." However, in spite of how often this notion appears in the daily life of the translator (expert and trainee), little has been achieved on this matter ${ }^{1}$.

When delving into the different contributions by the various authors that did focus their research on this topic we feel that they did not start with existing work, in order to give greater significance to what had already been discovered and, therefore, to complement the existing research on this matter and give more significance and consistence to it. In our wish to con-

1 The first contributions date from 1988 (Nord) and, 25 years later, we confirm that there is no consensus on this matter, essential for our discipline, which may be a symptom of how intermittent the research has been. 
tribute in a small way to this matter of great importance in the training of future translators, we will start from the existing contributions on this matter, in an attempt to offer a framework for the systematization of the development of the capacity to recognize, as well as the way to describe, the different translation problems that the translation students encounter during their training.

The general hypothesis from which we start is: the training received during Translation and Interpreting studies favor the development of translation competence and, particularly, of strategic competence.

Therefore, based on the proposals of Nord $(1988,1991)$ and PACTE $(2011 a, 2011 b)$ and the different encounters with the expert judges group ${ }^{2}$, who collaborated in our empirical study, we present the following classification of translation problems (Gregorio, 2014: 130-131) used in the data analysis of our empirical research:

1. Linguistic problems. These are problems related to the linguistic code, essentially at the lexical (non-specialized lexicon) and morphosyntactic level.

2. Textual problems. These are problems related to questions of coherence, thematic progression, cohesion, pictures, text typology (genre conventions), perspective, style, tone.

3. Cultural problems. These are problems which refer to cultural questions (presuppositions), related to principles, myths, perceptions, beliefs and behaviors and their textual representations, as well as their cultural differences.

4. Pragmatic problems. These are problems related to the text function (skopos), text intentionality, which derives from the translation brief, the characteristics of the text recipient, the context for the translation or the text space and/or formatting.

\section{Methodology}

It seems reasonable to think that, if there is no consensus on the theoretical questions that we aim to analyze in this empirical study, it is possible to sow doubt about the relevance of the results; however, the fact that there is no consensus does not mean that our study objective (the development of strategic competence) is not a topic seen practically every day in the classroom. It is obvious that during classes, in translator training centers, the students are taught to recognize and solve translation problems and, in order to do so, they have to be previously defined and described. So, with our study we do not intend to provide the mathe-

2 The expert judges group plays a fundamental role as a support network for the design of this empirical study, given the number of notions and concepts studied which lack consensus in our discipline. 
matization of a reality as complex as the development of translation competence as a result of the formal training received at a higher education center, since neither the CV nor the students' profiles and not even the TI are objective realities. However, our research does aim to be an exercise in scientificity, as a reinforcement to identify the reality that is the object of our study and reaffirm the need for a compendium of terms and concepts that facilitate the development of translation competence as part of learning routines 3 .

The methodological bases of this research are briefly described below: the design, the phases, the data collection strategies, the population in the study, and the process that has focused on the empirical study, as well as the guidelines used in the data analysis that will be presented in this paper.

\subsection{Design}

This tool, designed on paper, has two parts. The first one focuses on the sociodemographic data ("student profile"), where we record data such as working languages, intercultural experiences or the method of acquisition of a foreign language, among other aspects (Gregorio, forthcoming). In the second part, we have a pre-translation brief and a series of open questions related to this brief. The results presented in this paper correspond to the second part of the tool.

It should be noted that some of the main reasons that led us to choose the tool to be designed on paper are the advantages it offers for data collection, systematization, the large number of subjects that can be reached with each application (captive population, García, 2005: 180), as well as the opportunity it provides for the researcher to briefly present the objectives and the protocol to complete the tool at the beginning of each data collection session in order to solve any possible problems during the data collection phase ${ }^{4}$.

\subsection{Participants}

We decided to apply the most used strategy in cases where there is no access to the entire population. That is, to consider a portion of the population, known as a sample (Sierra, 1998: 179), which shares the population characteristics of our study (Gregorio, 2014: 104).

3 We draw from the premise that metalanguage will vary depending on the theoretical perspective, the school, as well as the linguistic combination (Delisle et al., 1999; Mayoral, 1999; Gambier in Gambier \& Van Doorslaer, 2009; Snell-Hornby in Gambier \& Van Doorslaer, 2009; Van Vaerenbergh in Gambier \& Van Doorslaer, 2009).

4 When the researcher requested the students' participation, she explained to them the use of the (anonymous) data and asked them to sign an informed consent that stated: "I have been precisely informed about the objectives of this research project, and I agree to participate and cooperate in it". 
It is important to understand that our study is not experimental, but exploratory. This fact has a great influence on the treatment of the sample as well as on the data analysis. Once it has been established that the representativeness of the sample is not statistical, we must understand that it was decided that the sampling would be defined from a non-probabilistic perspective (Rojas et al., 1998: 65; Fink, 2003: 16).

To ensure a higher representativeness in the sample, and because the participation of all the Tl centers in Spain was impossible, the selection of the centers was planned according to a series of criteria (Gregorio, 2014: 104-105) that can be summarized as follows:

1. Our wish to study a high number of Spanish centers with different characteristics, located in different geographical areas of Spain to avoid focusing our study only on one geographical area (north, south, east or west).

2. The need to include Spanish centers with different student cohorts (small, medium, large).

3. The private or public status of the center.

4. The offer of $A$ and $B$ languages.

5. Accessibility while planning the data collection phase of our empirical study.

Thus, the translation training centers that participated in our study were: Universidad de Granada (UGR), Universidad de Salamanca (USAL), Universitat Jaume I (UJI), Universidad Pablo de Olavide (UPO) and Universidad Pontificia de Comillas (UPCO). The criteria used to include the participating students respond, at all times, to our objectives, which is why the sample of our study consists of students that had just started (1st year) their TI studies and students who were about to graduate (4th year).

\subsubsection{Profile of the sample}

Students in the first weeks of the first year (after admission) and in the last weeks of the fourth year of studies (before graduation). In general terms, we can state that the first and fourth year students share quite a uniform profile as far as language combination, international experience or sociodemographic features are concerned. This fact is worthy of note if we bear in mind that our sample has a total of 1,046 students from five Spanish universities.

In the fourth year group, the majority (85.6\%) completed their studies aged between 21 and 24, which shows that the majority of the students complete their studies successfully in an (approximate) four year period. The first year students in our sample (655) tend to enter the Translation and Interpreting Degree (TID) from secondary education (Calvo, 2010: 434), so their ages range between 17 and 20, for more than $89.2 \%$ of the students in our sample. The first year students are mainly female (78.9\%), a tendency which remains constant in the fourth year group with $80.5 \%$. This fact coincides with the pink collar status of the translation profession, as shown in other existing studies (Calvo, 2010). 


\subsection{Data collection techniques}

The text included in the task was selected as a result of a process of reflection and selection of a suitable textual genre (García Izquierdo, 2000, 2012; Elena, 2011; Roiss, 2006a, 2006b), which is key to our research subject study. The text included in the tool is in Spanish because it is the official language of the centers where the research was performed, as well as to comply with our specific objective of analyzing the students' capacity to recognize and describe (translation was never required) possible translation problems found in the text. Likewise, the selection of the text source language is justified by the additional challenge that finding a similar text with the same type of problems in all B languages would have posed, as well as to avoid the answers of the students being related to a text with similar problems, which is why we finally selected a text with Spanish (the official language of all the participants of our study) as the A language. We are aware of the fact that a translation brief from an A language to a B language may involve increased difficulty when describing problems in the text, but we believe that it facilitates the comprehension of the text and minimizes the possible difficulties regarding the level that the participants of the study have in their B Language (Kelly, 2005: 139-140).

In short, the task consists of a pre-translation exercise, the same one for both the 1st and 4th year students, which includes a translation brief that states: "This text is part of the flight magazine of an airline. Imagine you have to translate it into your B language for it to be published in the same magazine. Read it carefully and go to the next page."

Immediately after the text, there are specific instructions explaining what the students must do once they had read the text, as well as a space to answer. In the first part of the task, there is a brief contextualization of where the translation is going to be published and the linguistic combination. In the second part, the objective of the task is emphasized: "there is no need to translate the text, only write down the translation problems that you identify (up to five) and describe how you could solve them."

\section{TABLE 1}

Text of the pre-translation brief

Tal como somos tomando el vermú en Zahara de la Sierra (Cádiz)

\section{El vermú de los domingos}

¿Qué hacen los españoles el domingo por la mañana? Tomar el aperitivo, también llamado el vermú. Para los españoles la mañana es aquel espacio de tiempo que finaliza a la hora de comer, que en este caso y además en domingo, se enlaza con el café y las pastas de la merienda sin darse uno cuenta. El vermú o el aperitivo es un acto social abierto a todas las edades y condiciones: padres llevan a sus retoños, los mayores se encuentran con sus hijos, vecinos con vecinos, jefes con empleados y amigos con enemigos. Todos en el mismo bar, más o menos entre la 1 y las 3 . El bar es el de toda la vida, sin moderneces, con el mismo Paco, Antoni o Patxi en la barra que, además, por suerte, está normalmente a tiro de piedra del portal de tu casa. Con tanto vecino, cuñado y amigo, tres o cuatro rondas no te las quita nadie. Menos mal que la ingesta alcohólica viene acompañada de ese fabuloso invento que es la tapa. Boquerones en vinagre, queso, croquetas, gambas con gabardina y un largo etcétera de variedades regionales. Una delicia de domingo. 
By reading the text, one can see that it has several translation problems, which is why the students were able to point out up to five of them5, without translating it, because our study is not focused on evaluating translations (product) 6 , which has been widely studied over time (García de Toro \& García Izquierdo, 2005: 16), but on learning about the process and the ability of the 1st and 4th year students to identify the different types of problems, as well as analyzing how they describe them.

The text included in our tool had an image (non-verbal element) and was subjected to detailed analysis by a group of expert judges ${ }^{7}$ to detect and establish the translation problems in the text, as well as their analysis. The categorization of the different translation problems in the text was the result of several group and individual meetings between the researcher and each expert.

So, and as a result of the meetings with the group of experts and the pre-analysis of the data we have, the results will be presented around four main axes that represent the translation problems that the group of experts detected in the text included in the tool, namely: linguistic problems, textual problems, cultural problems and pragmatic problems.

\subsection{Process}

The tool was administered at two points in the students' training: in the first weeks of the first year (after admission) and in the last weeks of the fourth year of their studies (before graduation).

\subsection{Data analysis}

As we have already pointed out, the data for our research was in paper format, which is why before the analysis we had to manually systematize our tool data to a format processable by the SPSS data package, that is, to have the data in a numerical and digital form. Like all other data, those corresponding to the open-ended questions were handwritten by the students. Therefore, all the participants' answers had to be digitalized. The digitalization process was carried out by a single researcher.

5 On this matter, our work partially coincides with the exercise proposed in the work sheet of La Rocca (2007: 221).

6 We are aware that the fact of not having requested the translation of the text implies a number of intrinsic limitations for our research, due to the fact that on many occasions the analysis that is made before the translation does not consider some problems that may be noticed when performing the translation.

7 The group of experts was composed by Dr. Barabino, Dr. Calvo, Dr. Gregorio, Dr. Kelly, Dr. Mayoral and Dr. Way. 


\section{Results and discussion}

The data analyzed in this paper are extracted from one of the tools (Gregorio, 2014) designed in the project that studied strategic competence development, for which both quantitative and qualitative approaches were used (mixed approach). The results of our research of a descriptive and qualitative nature shed some light and meaning on a fundamental, yet obscure and insufficiently studied question from an applied-empirical perspective: the development of translator competence in translation students. Therefore, we are aware that, given the ambiguity of the concepts presented here, the data is not exempt from debate, and we would like to point out that our results are based on the perception of its participants. The results obtained from our research present trends and perceptions applicable to our final sample of participants and must not be extrapolated to the hypothetical universe or the overall population (Sierra, 1998: 179).

\subsection{Linguistic problems}

Our research results show a certain tendency to concentrate on words. The fourth year group uses the denomination "term" more frequently to refer to linguistic problems, words or vocabulary in general. This tendency may be explained by an evolution in the students' metalanguage; in other words, the fourth year group is in constant contact with specialized translating and interpreting subjects which work with terms. Terms seem to catch their attention a priori (and preoccupy them) in most cases for the students of specialized translation, as in legal translation for example (Way, 2014). Thus, it is possible that the specialized translation subjects may have motivated the students' loss of perspective concerning the characteristics which allow a word to be considered a term.

\section{TABLE 2}

Number of students that recognize linguistic problems

\begin{tabular}{lcccc} 
& FREQUENCY & VALID \% & FREQUENCY & VALID \% \\
\cline { 2 - 5 } & \multicolumn{3}{c}{ 15t } & \multicolumn{3}{c}{ 4th } \\
\hline Yes & 535 & $81.7 \%$ & 333 & $85.2 \%$ \\
\hline No & 120 & $18.3 \%$ & 58 & $14.8 \%$ \\
\hline Total & 655 & $100 \%$ & 391 & $100 \%$ \\
\hline
\end{tabular}

According to these data, it is especially interesting that there are practically no differences between the percentage of students from one population group to the other regarding this type of problem.

It is necessary to digress to exemplify the type of answer provided by the students when explaining problems of this type. In this way, when it comes to shortening the qualitative 
information, we find that students describe the linguistic problems mainly around the following concepts: term (s), word (s), vocabulary-lexicon, set phrases / expressions, names (of meals) / dishes.

Below we show the number of students and the response percentage for the five categories that the group of experts pointed out as susceptible of being recognized by the students. Remarkably more than half of the students at both points in their training have problems with the vocabulary of the text, such as the words retoños, merienda, tapa, ronda, among others. On the other hand, at both points in their training the students indicate having problems, to different degrees, with other aspects, such as with the names of the dishes, $15.4 \%$ in the 1st year and $46.3 \%$ in the 4 th year. Likewise, another problem at the lexical level that was pointed out by quite a high percentage corresponds to the expressions or set phrases, indicated by $56 \%$ in the 1 st year and by $45.5 \%$ in the 4 th year. Finally, but to a lesser extent, the students of both population groups include as linguistic problems those related to syntactic and orthotypography matters at both points in their training:

\section{TABLE 3}

Number and type of linguistic problems recognized by the students

\begin{tabular}{|c|c|c|c|c|c|c|c|c|}
\hline \multirow[t]{3}{*}{ Linguistic } & \multicolumn{4}{|c|}{ FIRST YEAR } & \multicolumn{4}{|c|}{ FOURTH YEAR } \\
\hline & \multicolumn{2}{|c|}{ RECOGNIZED } & \multicolumn{2}{|c|}{ NOT RECOGNIZED } & \multicolumn{2}{|c|}{ RECOGNIZED } & \multicolumn{2}{|c|}{ NOT RECOGNIZED } \\
\hline & Frequency & $\%$ & Frequency & $\%$ & Frequency & $\%$ & Frequency & $\%$ \\
\hline $\begin{array}{l}\text { Linguistic: } \\
\text { vocabulary }\end{array}$ & 405 & $61.8 \%$ & 250 & $38.2 \%$ & 221 & $56.5 \%$ & 170 & $43.5 \%$ \\
\hline $\begin{array}{l}\text { Linguistic: names } \\
\text { of the dishes }\end{array}$ & 101 & $15.4 \%$ & 554 & $84.6 \%$ & 181 & $46.3 \%$ & 210 & $53.7 \%$ \\
\hline $\begin{array}{l}\text { Linguistic: } \\
\text { set phrases }\end{array}$ & 367 & $56 \%$ & 288 & $44 \%$ & 178 & $45.5 \%$ & 212 & $54.2 \%$ \\
\hline Syntax & 47 & $7.2 \%$ & 608 & $92.8 \%$ & 27 & $6.9 \%$ & 364 & $93.1 \%$ \\
\hline Orthotypography & 3 & $0.5 \%$ & 652 & $99.5 \%$ & 5 & $1.3 \%$ & 386 & $98.7 \%$ \\
\hline Total & 655 & & & $100 \%$ & 391 & & & $100 \%$ \\
\hline
\end{tabular}

This table indicates that in the first year the students show a tendency to concentrate on words, similar to the tendency they have in the fourth year. There are no significant differences between both population groups, except for the section related to the linguistic problems derived from the names of the dishes, which are identified by a greater number of the 4 th year students. This fact may be due to the experience they have acquired during their training by translating this type of texts, frequently used in translation classrooms. 


\subsection{Textual problems}

Our results show that these problems are not one of the most frequent types indicated by either the first or fourth year group students. This type of problem is recognized by $7.8 \%$ of the first year subjects and by $6.4 \%$ of the fourth year subjects. At this point in our research and based on the data we have collected, we cannot ascertain the causes for these figures.

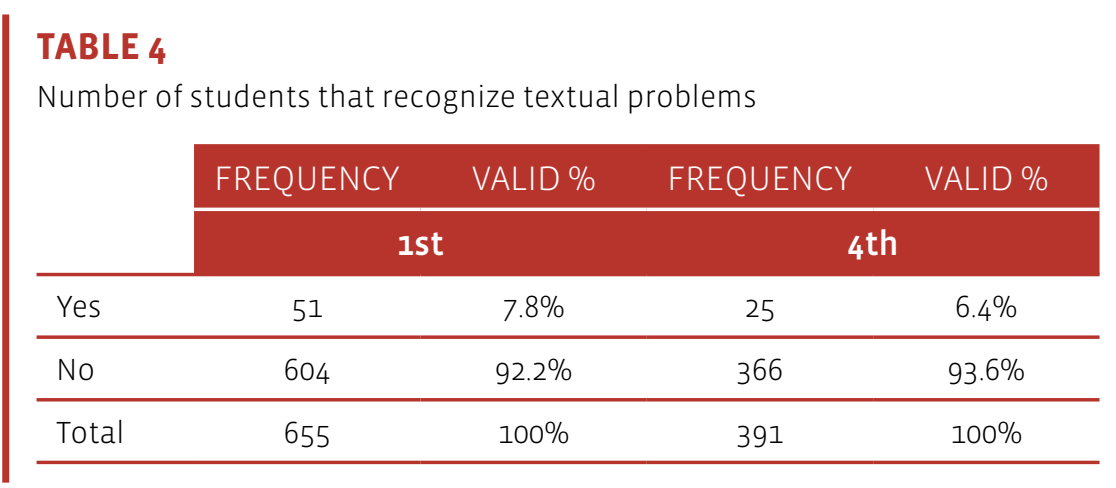

Among the possible textual problems, the students centered their attention mainly on problems related to the tone of the text (3.7\% in the first year group and $5.9 \%$ in the fourth year group); style was indicated as a problem by $1.1 \%$ of the first year group and by $4.1 \%$ in the fourth year group. Other aspects they indicated, although to a lesser extent, were perspective (0.3\% of the first year group and none of the fourth year group).

Besides, the students also indicated style, register and the image in the text as translation problems. It is particularly interesting to see that the percentage of students who recognize these three problems increases more than $2 \%$ in the fourth year group compared to the first year group. Style is indicated as a problem by $1.1 \%$ in the first year group and by $4.1 \%$ in the fourth year group. Register is indicated by $2.3 \%$ of the first year group, whilst $5.6 \%$ of the fourth year group does so. Finally, the image in the text is recognized as a translation problem by $0.3 \%$ of the first year group and by $2.8 \%$ in the fourth year group (see table 5 on the next page).

\subsection{Cultural problems}

These problems are recognized by the highest proportions of the first year group, with $71.3 \%$ and $79.5 \%$ of the fourth year group. We assume that these high percentages are due to the text topic and the dense load of concepts related to Spanish culture and similar aspects.

None of the these problems is indicated significantly more than others, with the exception of the concept of "tapa", indicated by $27.9 \%$ of the first year group and by el $26.6 \%$ of the fourth year group; "vermú", indicated by $32.2 \%$ of the first year group and by $39.9 \%$ of the fourth 


\section{TABLE 5}

Number and type of textual problems recognized by the students

\begin{tabular}{|c|c|c|c|c|c|c|c|c|}
\hline \multirow[t]{3}{*}{ Textual problems } & \multicolumn{4}{|c|}{ FIRST YEAR } & \multicolumn{4}{|c|}{ FOURTH YEAR } \\
\hline & \multicolumn{2}{|c|}{ RECOGNIZED } & \multicolumn{2}{|c|}{ NOT RECOGNIZED } & \multicolumn{2}{|c|}{ RECOGNIZED } & \multicolumn{2}{|c|}{ NOT RECOGNIZED } \\
\hline & Frequency & $\%$ & Frequency & $\%$ & Frequency & $\%$ & Frequency & $\%$ \\
\hline Tone & 24 & $3.7 \%$ & 631 & $96.3 \%$ & 23 & $5.9 \%$ & 368 & $94.1 \%$ \\
\hline Tenor & 2 & $0.3 \%$ & 653 & $99.7 \%$ & 1 & $0.3 \%$ & 390 & $99.7 \%$ \\
\hline Coherence & 3 & $0.5 \%$ & 652 & $99.5 \%$ & 1 & $0.3 \%$ & 390 & $99.7 \%$ \\
\hline Cohesion & $N / A^{8}$ & $\mathrm{~N} / \mathrm{A} \%$ & 655 & $100 \%$ & 2 & $0.5 \%$ & 389 & $99.5 \%$ \\
\hline Perspective & 2 & $0.3 \%$ & 653 & $99.7 \%$ & N/A & $\mathrm{N} / \mathrm{A} \%$ & 391 & $100 \%$ \\
\hline Style & 7 & $1.1 \%$ & 648 & $98.9 \%$ & 16 & $4.1 \%$ & 375 & $95.9 \%$ \\
\hline Image & 2 & $0.3 \%$ & 653 & $99.7 \%$ & 11 & $2.8 \%$ & 380 & $97.2 \%$ \\
\hline Total & 655 & & & $100 \%$ & 391 & & & $100 \%$ \\
\hline
\end{tabular}

\section{TABLE 6}

Number of students that recognize cultural problems

\begin{tabular}{lccccc} 
& FREQUENCY & VALID \% & FREQUENCY & VALID \% \\
\cline { 2 - 6 } & \multicolumn{3}{c}{ 1st } & \multicolumn{3}{c}{ 4th } \\
\hline Yes & 467 & $71.3 \%$ & 311 & $79.5 \%$ \\
\hline No & 188 & $28.7 \%$ & 80 & $20.5 \%$ \\
\hline Total & 655 & $100 \%$ & 391 & $100 \%$ \\
\hline
\end{tabular}

year group, and "proper names", indicated by $29.9 \%$ of the first year group and by $55.8 \%$ of the fourth year group. Finally, the concepts referring to "space" and to "locality" are the least identified cultural problems. In the case of questions relative to space, as the context in which the social activity of eating "tapas" occurs, it is noteworthy that none of the first year group identified it as a translation problem, whilst only $2 \%$ of the fourth year group did so. On the other hand, the localization of the text, present both in the body of the text and in the image caption, is indicated as a translation problem by $0.5 \%$ of both groups.

8 We have used N/A (not answered) in those cases where no problem of this nature was recognized. 
If we recall the categories identified by the group of experts regarding the assumptions related to food, these were: tapa, the concept of meal, dishes (regional variety) and merienda. In the case of the cultural assumptions related to the concept of bar, the group of experts identified the following9: bar, social act, vermú, kids in a bar, food in a bar and alcohol intake.

As shown in the table below, no percentage stands out significantly among the others, except perhaps tapa, which was identified as a cultural problem by $27.02 \%$ in the first year and by $35.13 \%$ in the fourth year, and the proper nouns:

\section{TABLE 7}

Number and type of cultural problems recognized by the students

\begin{tabular}{|c|c|c|c|c|c|c|c|c|}
\hline & \multicolumn{4}{|c|}{ FIRST YEAR } & \multicolumn{4}{|c|}{ FOURTH YEAR } \\
\hline & \multicolumn{2}{|c|}{ RECOGNIZED } & \multicolumn{2}{|c|}{ NOT RECOGNIZED } & \multicolumn{2}{|c|}{ RECOGNIZED } & \multicolumn{2}{|c|}{ NOT RECOGNIZED } \\
\hline & Frequency & $\%$ & Frequency & $\%$ & Frequency & $\%$ & Frequency & $\%$ \\
\hline Tapa & 183 & $27.9 \%$ & 472 & $72.1 \%$ & 104 & $26.6 \%$ & 287 & $73.4 \%$ \\
\hline "Comida" & 124 & $18.9 \%$ & 531 & $81.1 \%$ & 90 & $23 \%$ & 301 & $77 \%$ \\
\hline “Merienda" & 31 & $4.7 \%$ & 624 & $95.3 \%$ & 40 & $10.2 \%$ & 351 & $89.8 \%$ \\
\hline Vermú & 211 & $32.2 \%$ & 444 & $67.8 \%$ & 156 & $39.9 \%$ & 235 & $60.1 \%$ \\
\hline Alcohol intake & 10 & $1.5 \%$ & 645 & $98.5 \%$ & 6 & $1.5 \%$ & 385 & $98.5 \%$ \\
\hline Proper names & 196 & $29.9 \%$ & 459 & $70.1 \%$ & 218 & $55.8 \%$ & 173 & $44.2 \%$ \\
\hline $\begin{array}{l}\text { Regional variety } \\
\text { proper names }\end{array}$ & 1 & $0.2 \%$ & 654 & $99.8 \%$ & 16 & $4.1 \%$ & 375 & $95.9 \%$ \\
\hline $\begin{array}{l}\text { Interpersonal } \\
\text { relations }\end{array}$ & 11 & $1.7 \%$ & 644 & $98.3 \%$ & 7 & $1.8 \%$ & 384 & $98.2 \%$ \\
\hline Time concept & 14 & $2.1 \%$ & 641 & $97.9 \%$ & 4 & $1 \%$ & 387 & $99 \%$ \\
\hline $\begin{array}{l}\text { Week } \\
\text { organization } \\
\text { (Sunday) }\end{array}$ & 14 & $2.1 \%$ & 641 & $97.9 \%$ & 7 & $1.8 \%$ & 384 & $98.2 \%$ \\
\hline Mealtime (hours) & 70 & $10.7 \%$ & 585 & $89.3 \%$ & 58 & $14.8 \%$ & 333 & $85.2 \%$ \\
\hline Total & 655 & & & $100 \%$ & 391 & & & $100 \%$ \\
\hline
\end{tabular}

9 Some types are not included in the frequency tables due to the fact that no participating student of the research recognized these aspects, initially pointed out by the group of experts. 


\subsection{Pragmatic problems}

The problems in this category are indicated by $12.2 \%$ of the first year group and by $32.5 \%$ of the fourth year group. The difference between these percentages shows that recognizing this type of problem presents the greatest difference between the first and fourth year groups.

\begin{tabular}{|c|c|c|c|c|}
\hline & FREQUENCY & VALID \% & FREQUENCY & VALID \% \\
\hline & \multicolumn{2}{|c|}{$1 s t$} & \multicolumn{2}{|c|}{ 4th } \\
\hline Yes & 80 & $12.2 \%$ & 127 & $32.5 \%$ \\
\hline No & 575 & $87.7 \%$ & 264 & $67.5 \%$ \\
\hline Total & 655 & $100 \%$ & 391 & $100 \%$ \\
\hline
\end{tabular}

The students indicated six types of pragmatic problems: the brief, the receiver, the format, space, the function and intention. The brief is indicated as a translation problem by $0.3 \%$ of the first year group and by $2.8 \%$ of the fourth year group. The receiver, on the other hand, is indicated as a translation problem by $11.3 \%$ of the first year group and by $29.7 \%$ of the fourth year group, an interesting increase. Format is recognized as a translation problem by only $0.2 \%$ of the first year group and by $0.5 \%$ of the fourth year group. For space as a problem, we find that $0.5 \%$ of the first year group and a higher $3.3 \%$ of the fourth year group have indicated it. None of the first year group recognized text function as a translation problem, whilst only $1 \%$ of the fourth year group did so. Finally, the intention of the text is recognized by similar percentages in both groups: $1.2 \%$ in the first year group and $1.3 \%$ in the fourth year group. The results obtained show that the students seem to experience an evolution from their first to their fourth year regarding the pragmatic aspects involved in the translation process. As can be seen in table 9 (on the next page), the students recognize a greater number of problems of a pragmatic nature in the 4 th year.

\section{Conclusions}

The conclusions we present are extracted from the results of the students' replies to the questionnaire and the pre-translation task they were set. This implies that there may be some bias in the answers provided due to the specificities of the students' profiles. Thus, the conclusions we present cannot be extended to the whole population, despite the high participation rate in our study.

Nevertheless, we believe that both the descriptive nature of our study and the number of subjects involved, besides the common denominators reflected in our results, allow us to 


\section{TABLE 9}

Number and type of pragmatic problems recognized by the students

\begin{tabular}{lccccccccc}
\hline & \multicolumn{4}{c}{ FIRST YEAR } & \multicolumn{3}{c}{ FOURTH YEAR } \\
& \multicolumn{2}{c}{ RECOGNIZED } & \multicolumn{2}{c}{ NOT RECOGNIZED } & \multicolumn{2}{c}{ RECOGNIZED } & \multicolumn{2}{c}{ NOT RECOGNIZED } \\
\cline { 2 - 12 } & Frequency & $\%$ & Frequency & $\%$ & Frequency & $\%$ & Frequency & $\%$ \\
\hline brief & 2 & $0.3 \%$ & 653 & $99.7 \%$ & 11 & $2.8 \%$ & 380 & $97.2 \%$ \\
\hline recipient & 74 & $11.3 \%$ & 581 & $88.7 \%$ & 116 & $29.7 \%$ & 275 & $70.3 \%$ \\
\hline format & 1 & $0.2 \%$ & 654 & $99.8 \%$ & 2 & $0.5 \%$ & 389 & $99.5 \%$ \\
\hline space & 3 & $0.5 \%$ & 652 & $99.5 \%$ & 13 & $3.3 \%$ & 378 & $96.7 \%$ \\
\hline function & $\mathbf{N} / \mathrm{A}$ & $\mathrm{N} / \mathrm{A} \%$ & 655 & $100 \%$ & 4 & $1 \%$ & 387 & $99 \%$ \\
\hline intention & 8 & $1.2 \%$ & 647 & $100 \%$ & 5 & $1.3 \%$ & 386 & $08.7 \%$ \\
\hline Total & 655 & & & $100 \%$ & 391 & & & $100 \%$ \\
\hline
\end{tabular}

distinguish certain tendencies in the development of SC. In this vein, as mentioned above, the first and fourth year students have indicated different translation problems in the text used in our instrument.

One of the first conclusions we have reached is that there are no substantial differences between the first and fourth year students' ability to recognize a particular type of translation problem, although this fact is qualified and clarified by the results of the longitudinal study, as it included the same students in their first and fourth and final year of the TID. As far as linguistic problems are concerned, throughout our study we have found a certain tendency to dwell at the word level amongst the students of both groups of subjects. The main difference lies in the way in which they describe the translation problems, in their metalanguage, which represents conscious interiorization of theoretical concepts: the fourth year students use the denomination "term" more frequently when referring to linguistic problems, words or vocabulary in general. The results of our research show that textual problems do not attract the attention of either of the two groups of subjects, although the fourth year students do detect textual problems more than the first year students. The text in our instrument contained an image which occupied a large part of the page of the pre-translation exercise; it was practically ignored, however, by both groups of subjects. Another of the axes of our analysis was cultural problems, which were recognized by almost all the subjects in both groups. Our results, however, do not show any significant outstanding feature in either group. Finally, in view of the different percentages we can affirm that the ability to recognize pragmatic problems develops more than the ability to recognize other problems between the first and fourth years. 
As we have mentioned above, both the first and fourth year groups of students have indicated different translation problems in the text. One of the first conclusions we can reach based on the results obtained on the nature of the translation problems indicated by both groups of subjects is that there are no substantial differences in their ability to recognize particular types of translation problems, although this fact can be qualified according to the problems detected by the group of experts. One of the most rewarding results of this type of study is the number of prolific ideas that arose during and as result of the research process. This experience has made us detect some possible improvements regarding a future longitudinal case-study with similar characteristics in order to improve certain weaknesses or unanswered issues due to the lack of information. When it comes to planning our next study, we intend to have two groups (one of them as our control group). Also, we are going to design a smaller longitudinal study where the data of our tool will be completed by the translation of the assignment and retrospective interviews with the participating students to gain deeper knowledge of our field of study (translation competence), as well as with a series of meetings with the professors of the participants. In this way, we will be able to identify possible tendencies that indicate common or different factors that influence the ability to detect translation problems (such as ways of learning or teacher approaches), as part of the development of translation competence.

\section{Works cited}

Calvo Encinas, Elisa, 2010: Análisis curricular de los estudios de Traducción e Interpretación en España: perspectiva del estudiantado. PhD dissertation, Granada: Universidad de Granada.

Elena, Pilar, 2011: "Bases para la comprensión organizativa del texto”, Revista de Lingüística y Lenguas Aplicadas 6, 125-137.

Delisle, Jean, Hannelore Lee-Jahnke and Monique Cormier (eds.), 1999: Terminologie de la traduction/Translation terminology/Terminología de la traducción/Terminologie der übersetzung, Amsterdam and Philadelphia: John Benjamins.

FInk, Arlene, 2003: The Survey Handbook, Thousand Oaks: SAGE.

Gambier, Yves, and Luc van Doorslaer, 2009: The Metalanguage of Translation (vol. 20.), Amsterdam and Philadelphia: John Benjamins.

García de Toro, Cristina, and Isabel Garcia Izquierdo, 2005: "La práctica profesional de la traducción” in Cristina García de Toro and Isabel García IzQuierdo (eds.): Experiencias de traducción: Reflexiones desde la práctica traductora, Castellón: Universitat Jaume I, 15-30. 
García Ferrando, Manuel, 2005: "La encuesta” in Francisco Alvira, Jesús Ibañez and Manuel García (eds.): El análisis de la realidad social. Métodos y técnicas de investigación, Madrid: Alianza Editorial, 167-201.

Garcia IzQuierdo, Isabel, 2000: Análisis textual aplicado a la traducción, Valencia: Tirant lo Blanch.

GarcialzQuieRdo, Isabel, 2012:Competenciatextualparalatraducción, Valencia:Tirant Humanidades.

GILE, Daniel, 1995/2009: Basic Concepts and Models for Interpreter and Translator Training, Amsterdam and Philadelphia: John Benjamins.

Gregorio Cano, Ana, 2014: Estudio Empírico-descriptivo del Desarrollo de la Competencia Estratégica en la Formación de Traductores. PhD dissertation, Granada: Universidad de Granada.

Gregorio Cano, Ana, forthcoming: "El perfil de ingreso y egreso de los estudiantes de Traducción e Interpretación como elemento clave en el desarrollo de la competencia traductora”, Hermeneus 20.

Hurtado AlbiR, Amparo, 2011: Traducción y Traductología. Introducción a la Traductología, Madrid: Cátedra.

Hurtado Albir, Amparo (ed.), 2017: Researching Translation Competence by PACTE Group, Amsterdam: John Benjamins.

Kelly, Dorothy, 2002: "Un modelo de competencia traductora: bases para el diseño curricular", Puentes. Hacia Nuevas Investigaciones en la Mediación Intercultural 1, 9-20.

Kelly, Dorothy, 2005: A Handbook for Translator Trainers. A Guide to Reflective Practice, Manchester: St. Jerome.

La Rocca, Marcella, 2007: El taller de traducción: una metodología didáctica integradora para la enseñanza universitaria de la traducción. PhD dissertation, Vic: Universitat de Vic.

MAYORAL, Roberto, 1999: “La traducción de referencias culturales”, Sendebar 12, 67-88.

Mayoral, Roberto, 2001: Aspectos epistemológicos de la Traducción, Castellón de la Plana: Publicaciones de la Universitat Jaume I.

Nord, Christiane, 1988: Textanalyse und Übersetzen, Heidelberg: Gross.

Nord, Christiane, 1991/2005: Text Analysis in Translation. Theory, Methodology and Didactic Application of a Model for Translation-Oriented Text Analysis, Amsterdam: Rodopi. 
Nord, Christiane, 1997/2018: Translating as a Purposeful Activity, Functionalist Approaches Explained, Manchester: St. Jerome.

Orozco, Mariana, 2000: Instrumentos de medida de la adquisición de la competencia traductora: construcción y validación. PhD dissertation, Barcelona: Universitat Autònoma de Barcelona.

PACTE, 2011a: "Results of the Validation of the PACTE Translation Competence Model: Translation Problems and Translation Competence" in Cecilia ALvSTAD, Adelina HILD y Elisabet TISELIus (eds.): Methods and Strategies of Process Research: Integrative Approaches in Translation Studies, Amsterdam and Philadelphia: John Benjamins, 317-343.

PACTE, 2011b: "Results of the validation of the PACTE translation competence model: Translation project and dynamic translation index" in Sharon O'Brien (ed.): Cognitive Explorations of Translation, London / New York: Continuum Studies in Translation, 30-53.

PRESAS, Marisa, 1996: Problemes de traducció i competencia traductora. PhD dissertation, Barcelona: Universitat Autònoma de Barcelona.

Roıss, Silvia, 2006a: "El pacto de lectura y la adquisición de la competencia traductora: un ejemplo de traducción especializada inversa (español-German)", TRANS 10, 99-112.

Roıss, Silvia, 2006b: "Competencia traductora y tipología textual: En busca del punto de intersección”, Estudios Filológicos Alemanes 11, 439-450.

Rojas, Antonio, Juan Fernandez and Cristino Pérez (eds.), 1998: Investigar mediante encuestas. Fundamentos teóricos y aspectos prácticos, Madrid: Síntesis.

Shreve, Gregory, 1997: "Cognition and the evolution of translation competence" in Joseph Danks, Gregory Shreve, Stephen Fountain y Michael McBeath (eds.): Cognitive Processes in Translation and Interpreting, Thousand Oaks: Sage Publications, 120-136.

Sierra, Restituto, 1998: Técnicas de investigación social. Teoría y ejercicios, Madrid: Paraninfo.

WAY, Catherine, 2014: "Structuring a Legal Translation Course: a Framework for Decision-Making in Legal Translator Training” in Le Cheng, King KuI Siny and Anne WAGner (eds.): Ashgate Handbook of Legal Translation, United Kingdom: Ashgate Publishing, 135-152. 